\title{
Analysis on Value Evolution of Higher Vocational Teachers and Its Development Paths under the Big Data Background
}

\author{
Man Deng \\ Chongqing College of Electronic Engineering \\ Chongqing, China
}

\begin{abstract}
Traditional values, roles and positioning of higher vocational teachers are challenged under the big data background. Internet and information technology are altering educational forms. The core value orientation of higher vocational teachers is the innovation of vocational education that integrates information technology. The career development path of higher vocational teachers should be the professional development of informatization, which requires higher vocational teachers to actively learn new internet technology and combine it with teaching practice. Attentions from government, schools and society should be paid to career growth of higher vocational teachers.
\end{abstract}

Keywords-big data; higher vocational teachers; value evolution; development path

\section{INTRODUCTION}

Career development of higher vocational teachers lays foundation for the sound development of higher vocational education and improves its quality. Higher vocational education has occupied more than half of higher education. Higher vocational students have occupied above 60 percent of higher education and will reach up to 14.8 million by 2020 . The level of higher vocational education directly decides the manufacturing level of our country. However, higher vocational education is less popular because of the low educational quality. Its development is determined by teachers. At present, the educational revolution of big data brought by information technology has become the general trend. Big data of internet changes teaching forms and requires the revolution of teachers in vocational colleges. Knowledge revolution and transmission has broken the limitation of time and space. The information sources for higher vocational teachers and students are at the same level. Traditional values and position of teachers are challenged. Values and paths of career development become ambiguous. If traditional educational theories and ways are followed, higher vocational teachers will fall behind the times, lack experience and teaching theories and fail to influence students, finally influencing the quality of higher vocational education.

\section{INFLUENCE OF BIG DATA ON HIGHER VOCATIONAL EDUCATION AND TEACHERS}

\section{A. The Influence of Big Data on Higher Vocational Education}

Information technology and big data have profound influence on the system of higher vocational education. The "enormous" knowledge and indexation of knowledge update make learning contents ambiguous, complex and uncertain. Under the big data background, learners can study through database and network flow. Higher vocational students obtain educational resources through multiple ways. Learning style and process evolve into diversified integration process that centers on higher vocational students and involve tremendous knowledge. Instead of being passive receiver and consumer of knowledge, higher vocational students seek information through integrating fragmented educational resources. Information technology and big data are changing forms of higher vocational education. Influenced by efficient transmission of information technology, the geographical boundary of higher vocational colleges is vague. New technology turns informal learning into an important part of learning. Higher vocational colleges must alter development strategies and pursue "lifelong education" and "mass education" to serve the public. Functions of higher vocational colleges and evaluations on it will be popular and social. Higher vocational colleges are turned from the space for students to receive information to a social place for people to discuss and study.

Application of internet and new technology changes the process of teaching activities and makes teaching activities opener and replaces some educational functions of higher vocational teachers. Under the big data background, teaching and learning exist in different time and space. The communication between teachers and students is more equal and democratic. Teachers and students are equal partners. The traditional teaching activities of higher vocational teachers are overthrown. In the past, it is teacher-centered and values knowledge transfer, but now it is transformed into studentcentered integration and guidance that values knowledge resources. Teaching of higher vocational teachers is flipped from "teaching courses" into "teaching students". The flipped teaching pattern has better requirements for higher vocational 
teachers who should transfer from researching teaching contents to researching students and questions raised by them as well as solving problems. The teaching activities are opener and more diversified under big data background. The role of higher vocational teachers becomes diversified.

\section{B. Changes and Challenges Brought by Big Data for Higher Vocational Teachers}

Under the big data background, knowledge production, storage and transmission change into network flow, which makes them faster, low-cost and cover more people. Under this circumstance, higher vocational teachers and students are at the same level to acquire applied educational resources. The values of higher vocational teachers who serve as knowledge transmitter are weakened. The traditional teaching that higher vocational teachers teach applied technical knowledge to students is challenged. The big data transforms teachercentered teaching into student-centered teaching in higher vocational colleges. Students can watch videos and raise pertinent questions online or offline. Higher vocational teachers provide individualized education according to questions raised by students.

Under the big data background, the role of traditional teachers including higher vocational teachers is more diversified and professional. Higher vocational teachers can produce high quality educational resources with the help of informational technology and become expert teachers to serve the world. Meanwhile, they can help higher vocational students to integrate learning resources and guide and promote their learning. With the development of information technology and the transformation of learning and reading habits, the career development of higher vocational teachers is also challenged by new technology, which brings new revolution and learning styles. Higher vocational teachers have new understanding of courses and teaching, new practical ability and teaching patterns.

\section{ANALYSIS ON EVOLUTION OF CAREER VALUES OF HIGHER VOCATIONAL TEACHERS UNDER THE BIG DATA BACKGROUND}

Value orientation refers to the behavior disposition that subjects carry out value selection and value decision to achieve value goal under the guidance of value according to standard of value. Influenced by big data, higher vocational colleges sustain great responsibilities to train tremendous front line digitalized laborers and servers for the information society. Vice premier of the State Council proposes vocational education aims at improving the quality of talent training and insists on quality-centered connotative development. The career development of higher vocational teachers has significant influence on the construction of high quality higher vocational colleges, supporting the reform and innovation of higher vocational education under big data. Analysis on career development of higher vocational teachers under big data background must make sense of the transformation of career value and the value orientation of higher vocational teachers.

Marx and Engels conclude the history of human civilization as "the history of personal development", which is applicable to the evolution history of career values of higher vocational teachers. Productivity change promotes educational innovation and changes teachers' career values. Nowadays, education has broken the limitation of time and space under the influence of big data and information transmission. In the information era, higher vocational education should cultivate enormous primary and innovative digitalized laborers and servers. Higher vocational teachers must adapt to the teaching reform brought by big data. They are double-professionally-titled teachers to realize professional development with innovation of selfcentered concept, knowledge and skills, practical ability and education behaviors. The value orientation of higher vocational teachers changes accordingly. They should take the innovation of vocational education that integrates information technology as core value orientation. The innovation of vocational education includes the innovation of educational concept, knowledge and behaviors, involving and leading occupational activities of higher vocational teachers.

\section{ANALYSIS ON PATHS FOR CAREER DEVELOPMENT OF Higher Vocational TEACHERS UNDER THE BIG DATA BACKGROUND}

Educational reform under the big data background is the deep integration of education with information technology instead of simple digitalized application. Educational concepts, contents and methods will integrate with information technology comprehensively and bilaterally. Future learning is individualized and lifelong learning, for which the information technology create environment of ecological technology. Career of higher vocational teachers develops continuously and dynamically. Teachers must learn endless information technology and integrate it with teaching, in order to realize innovation of teaching styles and methods. Therefore, the career development paths of higher vocational teachers should be the professional information-based development that integrates information technology according to characteristics of higher vocational colleges.

\section{A. Individualized and Lifelong Learning under the Support of Big Data}

Individualized and lifelong learning that integrates information technology is an important part of the professional information-based development of higher vocational teachers. Information technology develops ceaselessly and rapidly. Learning information-based knowledge and disciplinary knowledge is essential to improve the professional development level of higher vocational teachers. In traditional educational training, teachers participate passively with enthusiasm. One of the roles of higher vocational teachers in the educational revolution under big data is learners. Therefore, career development of higher vocational teachers needs them to carry out individualized and lifelong learning. Under the big data background, higher vocational teachers are driven by selfrequirements to learn effectively, in order to solve problems in teaching practice.

Supported by big data, with more available resources, higher vocational teachers can learn online and choose traditional offline training. Big data and information technology are learning objects as well as resources of teachers, 
making individualized and lifelong learning of higher vocational teachers more efficient. Diversified digital resources such as MOOC, Micro-course, open class, network community and teaching platforms are provided for teachers to carry out cooperative learning, communicate with peer and enterprise experts and attend training online and offline. Thus they will form ecological learning system and promote sustainable and dynamic career growth.

\section{B. Collaborative Practice Supported by Big Data}

Under the big data background, higher vocational teachers are responsible to train application-oriented talents and servers to meet economic development. Except for teaching disciplinary knowledge, they provide science and technology service and guidance in enterprises. The development of higher vocational teachers that only depends on personal power is not enough. They must communicate and cooperate with peer and enterprises to growth together. Collaboration practice of higher vocational teachers under the support of big data includes the practice of learning community supported by big data and the practice of teachers' development activities to improve their professional abilities.

Higher vocational teachers exchange experience and share knowledge on communication platform of internet. Academic exchanges supported by big data and information technology are more extensive and deeper. Teachers grow faster with more extensive support of career development. The Minister of Education Yuan Guiren proposes on working conference of vocational education and adult education that Achilles' heel as well as the key point of vocational education development is cooperation between school and enterprise, which must be explored and solved. The growth of higher vocational teachers is inseparable from real environment of enterprises. Centers for Faculty Development continuously established in higher vocational colleges systematically understand requirements of enterprises, teachers' professional expertise, expand ways for teachers to practice in enterprises and enhance the effects, promoting the development of higher vocational teachers' innovative thinking and ability.

\section{Reflective Practice Supported by Big Data}

Reflective practice is important mechanism for selfdevelopment of higher vocational teachers. As professionals of higher vocational education, higher vocational teachers have progressive development process. Reflective practice enables higher vocational teachers to continuously improve and realize educational innovation through analyzing teaching activities and accumulating teaching experience. The development of information technology supports reflective practice of higher vocational teachers and creates opportunities for educational innovation.

Teachers carry out teaching reflection through information literacy and internet. Introduction of technology in education adds the ability of technological and educational application to the professional development of teachers. With the soaring development of internet, teaching reflection tools such as blogs, forum and network reflection platform are designed and applied. Higher vocational teachers can acquire feedback of experts, peer and students to carry out teaching reflection through electronic portfolio and network communication tools. The reflection of higher vocational teachers is supported by: (1) technological tools that record teaching activities such as record, video and electronic portfolio; (2) technological tools that record reflection results such as blogs and weibo; (3) technological tools that assist reflection such as email, WeChat group, qq group and online education theme BBS.

\section{CONCLUSION}

Educational reform under big data has happened. The key point of reform is "T" (Technology) instead of "I" (Information). Higher vocational teachers pay attention to "I" (Information) and data in reflection. With the development of educational reform, tremendous and real teaching data of higher vocational education have appeared after we use online teaching platforms. Teaching data supported by information technology resemble magical diamond mine waiting for higher vocational teachers to analyze and reuse. Analysis and reuse of teaching data are reflection and educational innovation.

\section{REFERENCES}

[1] Wang Ping. Research on Improving Teachers' Wisdom in the Big Data Era [J], Open Education Research, 2015, (3): 30-39

[2] Tang Min, MOOC Revolution [M], Beijing, CHINA CITIC PRESS, the 1st Edition in January 2015

[3] Deng Man. Challenges of Career Development of Higher Vocational Teachers and Countermeasures under the Background of Internet-based Education [J], Education and Vocation, 2016(10): 70-71

[4] Zhang Jinliang, He Gaoda. Learning Analysis: Promoting Online Professional Development of University Teachers in the Big Data Era, Journal of Distance Education, 2014(1)

[5] Big Data Era, (Britain) Mayer-Schonberger, (Britain) Cukier, translated by Sheng Yangyan, Zhou Tao, December 2012, Zhejiang People's Publishing House 